\title{
An Empirical Investigation on Religious Diversity Practices at Malaysian Private and Public Sectors
}

\author{
Marhanum Che Mohd Salleh ${ }^{1 *}$, Nik Ahmad Kamal Nik Mahmod², Azmi Bin Harun², Azizah \\ Mohd $^{2}$, Noor Azlan B. Mohd Noor ${ }^{3}$, \& Rahmawati Binti Mohd Yusoff ${ }^{4}$ \\ ${ }^{1}$ Department of Finance, International Islamic University Malaysia \\ ${ }^{2}$ Department of Civil Law, Ahmad Ibrahim Kulliyyah of Laws, International Islamic University \\ Malaysia, Kuala Lumpur, Malaysia \\ ${ }^{3}$ Department of Sociology and Anthropology, Kulliyyah of Islamic Revealed Knowledge and \\ Human Sciences, International Islamic University Malaysia, Kuala Lumpur, Malaysia, \\ ${ }^{4}$ Department of Law, University Teknologi MARA, Cawangan Johor, Kampus Segamat, Johor, \\ Malaysia. \\ DOI - http://doi.org/10.37502/IJSMR.2021.4504
}

\begin{abstract}
This research investigates religious diversity practices at Malaysian public and private sectors. Among the important aspects that have been examined are company policy, dress code, religious symbols or artifacts, recruitment, promotion, training, religious observances, and facilities. Quantitative methodology is adopted to achieve the research objective where a total of 759 employees from both public and private sectors are surveyed. Based on statistical analyses performed in this research (descriptive and factor analysis), religious freedom is practiced in most of the public and private sector workplaces in Malaysia with multicultural and multi-religious society. Results of this study may indicate that there were no issues of religious discrimination among workers of public and private sectors in Malaysia. As this research is conducted from the workers' perspective, there is always scope of further research on the same matter from the employers' point of view.
\end{abstract}

Keywords: Religious Diversity, Malaysia, Survey, Private and Public Sectors, Factor Analysis.

\section{Introduction}

\section{Background of Research}

Malaysia is a multi-cultural, multi-racial and multi-religious country (Mohd Arip et al., 2015). People of numerous cultures, race and religion have been living here in peace and harmony since the independence in 1957. Religious tolerance in Malaysia is recognized by many and argued by a few. The existence and preservation of religious tolerance and coherence among Malaysian multi-religious and multi-racial citizens is one of the many factors contributed towards economic development and growth in Malaysia (Abubakar, 2013). 


\section{1 | International Journal of Scientific and Management Research 4(5) 80-96}

According to the 2010 Population and Housing Census of Malaysia (Census 2010) conducted by the Malaysian Department of Statistics, out of the total population 61.3 percent are Sunni Muslims; 19.8 percent are Buddhists; 9.2 percent are Christians; 6.3 percent are Hindus; 1.3 percent are followers of traditional Chinese religions, such as Confucianism and Taoism; and 0.4 percent are the believers of 'other religions', including indigenous religious practices (Department of Statistics Malaysia, Population Distribution and Basic Demographic Characteristic Report 2010). The Federal Constitution of Malaysia offers broad protections for freedom of religion or belief. Although it establishes Islam as the national religion, it also assures that other religions shall be practised in peace and harmony (The Federal Constitution of Malaysia).

The diversity of races in Malaysia also contributed to diversity of religion practices in the workplaces as people from different religions are employed in public and private sector workplaces. As the workforce in Malaysia is becoming more diversified in terms of religion, many individual values are carried over to the workplace. Therefore, employees are most likely to bring their religious beliefs with them to the office (Messarra, 2014). Studies suggest that organizations that frankly encourage their employees to express their religious belief tends to become more successful (Arnaldo, 2004). But, to what extent religious diversity practices are allowed in public and private sector workplaces in Malaysia? Whether there is discrimination in workplaces based on religion, whether the employees are satisfied with the current diversity practices inside their organizations, whether religious diversity practices increase productivity. These are million-dollar questions yet to be addressed in the context of Malaysia. Till date, there is a very few scholarly works worldwide that focuses on religious diversity practices within organization, probably none in Malaysia. Thus, purpose of this study is to identify the extent of religious diversity practices in public and private sector workplaces in Malaysia with regard to several aspects, i.e. company policy, dress code, religious symbols or artifacts, recruitment, promotion, training, religious observances, facilities etc. The study opens with a literature review on the nature and extent of religious diversity and religious freedom in Malaysia in general and at workplaces in particular. Then, the methodology is presented followed by data analysis, a discussion of the results, findings and conclusion.

\section{Literature Review}

The current study concerns about religious diversity practices at public and private sector workplaces in Malaysia including employee's freedom to profess and practice his religion. There are many studies, research and discussions about rights of workers at their workplaces. These rights are already in the law, be it domestic legislation or international standards and conventions. Nonetheless, there is not much literature on the diversity practices of workers at the workplaces in the context of Malaysia. To answer the research question and finding out the research objectives, it is necessary to review relevant literatures so that the existing gaps are identifies and filled up. For the purpose of the research, numerous statutes, international treaties, law journals, reports of national and international organizations and government agencies, books etc. have been reviewed. 


\section{2 | International Journal of Scientific and Management Research 4(5) 80-96}

According to Lucy Vickers (2015), although freedom of religion is well established as a fundamental right, to what extent it should be enjoyed in the workplace is still the subject of some debate. Some may argue that religion is a private matter that has no place at work. However, most of them believe that work is a forum in which a significant part of life is lived. It is where people meet others, engage with wider society, gain economic benefit, undertake personal and professional development, and to some extent, express their personality. If considered that way, religion should not be excluded from the workplace. However, studies also shown that protecting religious freedom at work can lead to tension; tension between equality rights and tension between religious and other interests such as the economic interests of employers. So, she found both positive and negative impacts of religious diversity practices at the workplaces. In every multicultural society in the world including Malaysia, religious tolerance and religious diversity practices is one of the important aspects in all sectors. Religious diversity in Malaysia is acknowledged by many and disputed by few. One of the many factors contributed to Malaysian economic development and growth is the existence and maintenance of religious diversity, tolerance and harmony among Malaysian multi-religious and multi-racial citizens in both public and private sectors (Abubakar, 2013).

In Malaysia, religion is not a basis or criterion for employment unless the employment is connected to or related with the affairs of any religion or any religious institution or body managed by a particular religious group. For example, an imam or leader in a mosque must be a Muslim and a Christian in a church and a Buddhist in a Buddhist temple and a Hindu in a Hindu temple (Abubakar, 2013). The Federal Constitution of Malaysia states that there shall be no discrimination against citizens on the ground only of religion, race, descent, place of birth or gender in any law or in the appointment to any office or employment under a public authority or in the administration of any law relating to the acquisition, holding or disposition of property or the establishing or carrying on of any trade, business, profession, vocation or employment (The Federal Constitution of Malaysia, Article 8(2). So, religious diversity at workplaces is well recognised by the Federal Constitution of Malaysia.

The Federal Constitution also assures that every person has the right to profess and practice his religion, and to propagate it (The Federal Constitution of Malaysia, Article 11(1)). There are also limitations of the right to profess and practice one's religion on the ground of public order, public health and morality (The Federal Constitution of Malaysia, Article 11(5)). So far there is no decision made by the court that touches on the right to profess and practice one's religion in the workplace. But there are cases like Meor Atiqulrahman Ishak \& Others V. Fatimah Sihi \& Others (Atiqulrahman Ishak \& Others V. Fatimah Sihi \& Others [2006] 4 CLJ 1), and Halimatussadiah v Public Services Commission (Halimatussadiah v Public Services Commission [1994] 3 MLJ 61) dwelled into issues about the right to wear "Islamic" dress. The International Commission of Jurists (ICJ) has identified a number of challenges to maintain religious diversity in Malaysia. In a recent paper they identified six key issues concerning the implementation in practice of 


\section{3 | International Journal of Scientific and Management Research 4(5) 80-96}

constitutional provisions, federal laws and Islamic laws in the context of freedom of religion or belief:

1. Discrimination against religious minorities;

2. Limitations on the rights of children relating to personal matters governed by Islamic law;

3. Discrimination against persons who wish to change or adopt a new religion;

4. Criminalization and prosecution of proselytism among Muslims; and

5. Prohibitions on the use of the word 'Allah' by non-Muslims; and

6. Relationship with freedom of expression and the crime of sedition.

To help address these concerns and assist the Government of Malaysia to ensure that its legal framework is implemented in accordance with international human rights law and fully protects freedom of religion or belief in all sphere of life including workplaces, the ICJ offered some recommendations which includes becoming party to major international treaties, withdrawing reservations to CEDAW, CRC, CRPD etc, implementing the provision of the Constitution, amend or repeal relevant laws, and others. A study by Kadiresan and Javed (2015) on discrimination in employment and task delegation at workplaces in Malaysia have touched on many aspects of employment discrimination including religious discrimination at workplaces. Empirical survey conducted on employees from various private organizations in the state of Kuala Lumpur have revealed that the existence of discrimination at the workplace in Malaysia regarding age, race, religion and gender are still felt in subtle forms. Most of the respondents felt that race is a major factor although the other factors like age, religion and gender hold significance as well. This study is somewhat familiar with the current research but only limited to state of Kuala Lumpur whereas the current study covers all the states of Malaysia.

Although it is expected that employees in an organization should have freedom to profess his religious faith, studies suggest that religious freedom in workplace may also affect the working environment. In a study on organizational behaviour Messarra surveyed 548 employees working in religiously diverse organizations. The findings suggested that when workers perceive religious discrimination in their group, their dedication and participation are affected. The study suggested that managers should devise strategies and develop management interventions to mitigate the negative organizational and personal consequences of religious discrimination in the workplace. Messara defined religious discrimination as "valuing or treating a person or group differently because of what they do or do not believe or because of their feelings towards a given religion (Messarra, 2014). Based on the religious tolerance and harmony found in major religions of the world, it is very clear, evident, reasonable and sound to deduce that in Malaysia followers of every religion have preferred the religious tolerance and harmony found in their respective religions in every sector including public and private sector workplaces. They are able to maintain and nurture

This religious diversity because they are strongly supported by the constitutional and other legal provisions as well as by some policies implemented by government (Abubakar, 2013: 92). According to Abdul Rahmam and Mohd Khambali@Hambali (2013), religious diversity is a reality that must be acknowledged. The varieties in religion contain claims and needs to be judged properly. A good approach would result in a good situation and vice versa. Tolerance is a culture 
that founded the co-existence of pluralistic society in Malaysia. The culture of tolerance can only be built if ethnical tolerance and religious tolerance is accepted as a common practice, i.e. all alike irrespective of their religious belief. The studies cited above provide a lot of information on religious freedom, religious diversity, tolerance and practices in Malaysia as a whole and its positive and negative impact. But none of these literatures could either answer the research questions or fulfil the objectives of the current study, i.e. religious diversity practices in public and private sector workplaces in Malaysia. It is also observed that there are a very few studies on religious freedom at workplaces in the context of Malaysia. Thus, the current study is unique in nature and one of its kind in Malaysia. It explores the extent of religious diversity practices in public and private sectors in Malaysia based on different variables such as, company policy, dress code, religious symbols or artifacts, recruitment, promotion, training, religious observances, facilities, and also employees' satisfaction towards religious practices at their workplaces and also considers the necessity of a separate legislation dealing with this particular area.

\section{Research Methodology}

This research is done quantitatively where the empirical data is gathered through survey of 759 employees from public and private sectors in Malaysia. In terms of analysis, descriptive and factor analyses is conducted to achieve the research objectives. A total of 10 numerators is employed to disseminate survey to all states in Malaysia. They were briefed on the targeted group of sample and industry concerned.

\section{Sampling}

Overall, 14 states in Malaysia have involved in this research and a total of five variables is explored on the religious treatment at workplaces which are company policy, dress code, religious symbols or artifacts, recruitment/training, religious observances, and facilities.

\section{Research Instrument}

Survey instrument were basically formed by adopting and adapting past literatures' instrument which including by European Network against Racism (2015) and Abdullah et al. (2016). All the instruments is divided into specific variables and sections in the survey form. Apart of the instrument, the survey form also consists of demographic and work-related questions.

\section{Data Analysis}

\section{Background of Respondents}

Descriptive Analysis is conducted to observe respondents' background including gender, age, ethnic, religion, marital status, and education level. Overall, 61 percent of the respondents were female and the rest 39 percent were male. Majority of them were belong to 21-35 years old age group (61 percent), Malay ( 88 percent), Muslim (92 percent), and married (52 percent). In terms of educational level, 36 percent were degree holder, and diploma and upper school level share similar percentage which is 21 percent. Details background of respondents is summarized in Table 1 below. 
85 | International Journal of Scientific and Management Research 4(5) 80-96

Table 1: Background of Respondents

\begin{tabular}{|c|c|c|c|c|}
\hline No. & \multicolumn{2}{|l|}{ Background } & Frequency & Percentage \\
\hline \multirow[t]{3}{*}{1} & \multirow[t]{3}{*}{ Gender } & Male & 299 & 39.4 \\
\hline & & Female & 460 & 60.6 \\
\hline & & Total & 759 & 100.0 \\
\hline \multirow[t]{11}{*}{2} & \multirow[t]{11}{*}{ Age } & Under 20 years old & 40 & 5.3 \\
\hline & & $21-25$ years & 198 & 26 \\
\hline & & $26-30$ years & 163 & 21.5 \\
\hline & & $31-35$ years & 101 & 13.3 \\
\hline & & $36-40$ years & 94 & 12.4 \\
\hline & & $41-45$ years & 49 & 6.5 \\
\hline & & $46-50$ years & 51 & 6.7 \\
\hline & & \begin{tabular}{|l}
$51-55$ years \\
\end{tabular} & 40 & 5.3 \\
\hline & & \begin{tabular}{|l}
$56-60$ years \\
\end{tabular} & 17 & 2.2 \\
\hline & & Above 60 years & 06 & 0.8 \\
\hline & & \begin{tabular}{|l|} 
Total \\
\end{tabular} & 759 & 100.0 \\
\hline \multirow[t]{6}{*}{3.} & \multirow[t]{6}{*}{ Ethnicity } & Malay & 671 & 88.4 \\
\hline & & Chinese & 35 & 4.6 \\
\hline & & Indian & 16 & 2.1 \\
\hline & & Other Bumiputra & 30 & 4.0 \\
\hline & & \begin{tabular}{|l|} 
Others \\
\end{tabular} & 07 & 0.9 \\
\hline & & \begin{tabular}{|l|} 
Total \\
\end{tabular} & 759 & 100.0 \\
\hline \multirow[t]{6}{*}{4.} & \multirow[t]{6}{*}{ Religion } & Islam & 698 & 92.0 \\
\hline & & \begin{tabular}{|l|} 
Buddhism \\
\end{tabular} & 30 & 4.0 \\
\hline & & \begin{tabular}{|l|} 
Hinduism \\
\end{tabular} & 13 & 1.7 \\
\hline & & Christianity & 17 & 2.2 \\
\hline & & Others & 01 & 0.1 \\
\hline & & Total & 759 & 100.0 \\
\hline \multirow[t]{5}{*}{5.} & \multirow[t]{5}{*}{ Marital Status } & Single & 346 & 45.6 \\
\hline & & Married & 395 & 52.1 \\
\hline & & Divorced & 07 & 0.9 \\
\hline & & Widowed & 11 & 1.4 \\
\hline & & Total & 759 & 100.0 \\
\hline \multirow[t]{11}{*}{6.} & \multirow[t]{11}{*}{ Education Level } & $\mathrm{PhD}$ & 16 & 2.1 \\
\hline & & Master & 60 & 7.9 \\
\hline & & Degree & 278 & 36.6 \\
\hline & & Diploma & 159 & 20.9 \\
\hline & & Certificate & 57 & 07.5 \\
\hline & & \begin{tabular}{|l|} 
Upper Secondary \\
\end{tabular} & 156 & 20.6 \\
\hline & & Lower Secondary & 22 & 2.9 \\
\hline & & Primary & 07 & 0.9 \\
\hline & & No Schooling & 03 & 0.4 \\
\hline & & Others & 01 & 0.1 \\
\hline & & \begin{tabular}{|l|} 
Total \\
\end{tabular} & 759 & 100.0 \\
\hline
\end{tabular}




\section{Workplace Information}

Detailed analysis is also conducted to observe respondents' workplace information that includes their workplace location, work sector, work industries, role at work, total duration of work, duration of work in Malaysia, and duration with current employer. Highest 13 percent employees work in $\mathrm{KL}$ and lowest 0.3 percent in Sarawak while other states represent an average range from 47 to 53. Majority of them work in private sectors (63.9 percent), in service industries ( 71 percent), in diversified roles including clerical, sales, executive and others and work 6-8 hours a day (61.4 percent). 36 percent have been working for 10 years or more in Malaysia out of whom 26.6 percent with the same employer. Details workplace information of the respondents is summarized in Table 2 below.

Table 2: Workplaces Information

\begin{tabular}{|c|c|c|c|c|}
\hline No. & Workplace Informa & & Frequency & Percentage \\
\hline \multirow[t]{16}{*}{1.} & \multirow[t]{16}{*}{ Workplace Location } & Johor & 53 & 7.0 \\
\hline & & Kedah & 51 & 6.7 \\
\hline & & Kelantan & 49 & 6.5 \\
\hline & & $\mathrm{KL}$ & 99 & 13.0 \\
\hline & & Melaka & 48 & 6.3 \\
\hline & & Negeri Sembilan & 47 & 6.2 \\
\hline & & Pahang & 51 & 6.7 \\
\hline & & Perak & 52 & 6.9 \\
\hline & & Perlis & 50 & 6.6 \\
\hline & & P. Pinang & 51 & 6.7 \\
\hline & & Putrajaya & 52 & 6.9 \\
\hline & & Terengganu & 51 & 6.7 \\
\hline & & Sabah \& Labuan & 50 & 6.6 \\
\hline & & Sarawak & 02 & 0.3 \\
\hline & & Selangor & 53 & 7.1 \\
\hline & & Total & 759 & 100.0 \\
\hline \multirow[t]{5}{*}{2.} & \multirow[t]{5}{*}{ Work Sector } & Public & 207 & 27.3 \\
\hline & & Private & 485 & 63.9 \\
\hline & & NGO & 20 & 2.6 \\
\hline & & Others & 47 & 6.2 \\
\hline & & Total & 759 & 100.0 \\
\hline \multirow[t]{4}{*}{3.} & \multirow[t]{4}{*}{ Work Industries } & Manufacturing & 84 & 11.1 \\
\hline & & Services & 539 & 71.0 \\
\hline & & Others & 136 & 17.9 \\
\hline & & Total & 759 & 100.0 \\
\hline 4. & Role at Work & Clerical & 134 & 17.7 \\
\hline
\end{tabular}


87 | International Journal of Scientific and Management Research 4(5) 80-96

\begin{tabular}{|c|c|c|c|c|}
\hline & & Sales & 105 & 13.8 \\
\hline & & Design & 12 & 1.6 \\
\hline & & Marketing & 33 & 4.3 \\
\hline & & Executive & 148 & 19.5 \\
\hline & & Production & 34 & 4.5 \\
\hline & & Others & 293 & 38.6 \\
\hline & & Total & 759 & 100.0 \\
\hline 5. & \multirow[t]{5}{*}{ Work Duration } & 5 hours \&less & 20 & 2.6 \\
\hline \multirow{2}{*}{5} & & $6-8$ hours & 466 & 61.4 \\
\hline & & 9-11 hours & 239 & 31.5 \\
\hline & & 12 hours $\&$ more & 34 & 4.5 \\
\hline & & Total & 759 & 100.0 \\
\hline \multirow[t]{5}{*}{6.} & \multirow{5}{*}{$\begin{array}{l}\text { How long working in } \\
\text { Malaysia }\end{array}$} & 1 year or less & 124 & 16.3 \\
\hline & & $2-5$ years & 236 & 31.1 \\
\hline & & 6-10 years & 126 & 16.6 \\
\hline & & 10 years or more & 273 & 36.0 \\
\hline & & Total & 759 & 100.0 \\
\hline \multirow[t]{5}{*}{7.} & \multirow{5}{*}{$\begin{array}{l}\text { How long working } \\
\text { with same employer }\end{array}$} & 1 year or less & 226 & 29.8 \\
\hline & & $2-5$ years & 227 & 29.9 \\
\hline & & 6-10 years & 105 & 13.8 \\
\hline & & 10 years or more & 201 & 26.5 \\
\hline & & Total & 759 & 100.0 \\
\hline
\end{tabular}

\section{Religious Diversity Practices}

In this section, descriptive analysis is conducted to observe respondents' religious diversity practices on five variables, for example, company policy, religious symbols or artifacts, recruitment, promotion, and training, religious observances and religious facilities at their workplaces. In case of all the variables, the respondents agree that they are satisfied with the religious diversity practices within their workplaces. Detailed responses of the respondents are summarized in Table 3-7 below. 
Table 3: Company Policy

\begin{tabular}{|l|l|l|l|}
\hline No. & Item & Mean & $\begin{array}{l}\text { Standard } \\
\text { deviation }\end{array}$ \\
\hline CA1 & $\begin{array}{l}\text { There are clear written policies and practices in dealing } \\
\text { with religious freedom at my workplace such as the } \\
\text { religious dress codes, religious harassment, etc. }\end{array}$ & 3.6640 & 1.11083 \\
\hline CA2 & $\begin{array}{l}\text { I am aware about the do's and don'ts regarding religious } \\
\text { freedom at the workplace. }\end{array}$ & $\mathbf{4 . 1 5 5 5}$ & .79879 \\
\hline CA3 & $\begin{array}{l}\text { My organization offer guidelines to me in relation to } \\
\text { religious tolerance at workplace. }\end{array}$ & 3.7576 & .95919 \\
\hline CA4 & $\begin{array}{l}\text { My employer gives the right to me to manifest my } \\
\text { religion either alone or in groups. }\end{array}$ & 3.9065 & .91913 \\
\hline CA5 & $\begin{array}{l}\text { The company policy at my workplace has effectively } \\
\text { allows me to reconcile their religious needs. }\end{array}$ & 4.1357 & .82429 \\
\hline CA6 & $\begin{array}{l}\text { I am committed to comply with the legislation outlined } \\
\text { in relation to the religious freedom at my workplace. }\end{array}$ & 4.0711 & .83315 \\
\hline CA7 & $\begin{array}{l}\text { Company policy does not restrict to hire only those who } \\
\text { have certain religious background. }\end{array}$ & $\mathbf{3 . 6 3 8}$ & 1.1687 \\
\hline
\end{tabular}

Note: Scale 1=Strong Disagree, 2=Disagree, 3=Neutral, 4=Agree, 5=Strongly Agree

Table 3 shows that statement CA2 titled 'I am aware about the do's and don'ts regarding religious freedom at the workplace' has the highest mean value (4.156). This indicates that the workers are mostly aware about the rules regarding religious freedom at their workplaces. Further, most of them agree that the company policy at their workplaces has effectively allows them to reconcile their religious needs (mean $=4.136$ ). Hence, they are a bit neutral about the statement in CA7 titled 'company policy does not restrict to hire only those who have certain religious background' which has the lowest mean value (3.638). Overall, it is observed that most of the workers are positive in terms of inclusion of religious freedom and religious practices in the company policy.

\section{Table 4: Religious Symbols}

\begin{tabular}{|l|l|l|l|}
\hline No. & Item & Mean & $\begin{array}{l}\text { Standard } \\
\text { deviation }\end{array}$ \\
\hline CB1 & $\begin{array}{l}\text { My employer respects my freedom of dressing according } \\
\text { to my religious beliefs. }\end{array}$ & $\mathbf{4 . 0 9 2 2}$ & .94265 \\
\hline CB2 & $\begin{array}{l}\text { My employer give freedom to me to display religious } \\
\text { decorations in the workplace. }\end{array}$ & $\mathbf{3 . 5 8 2 3}$ & 1.11159 \\
\hline CB3 & I am free to wear any religious symbols at workplace. & 3.6219 & 2.84110 \\
\hline CB4 & $\begin{array}{l}\text { My employer does not impose restrictions on the wearing } \\
\text { of religious dress such as headscarves or turbans. }\end{array}$ & 4.0501 & 1.00664 \\
\hline CB5 & I am free to use any religious words at my workplace. & 3.8669 & 1.02190 \\
\hline CB6 & $\begin{array}{l}\text { I am free to discuss any religious matters or activities } \\
\text { with my colleagues at my workplace. }\end{array}$ & 3.8748 & 0.98076 \\
\hline
\end{tabular}

Note: Scale 1=Strong Disagree, 2=Disagree, 3=Neutral, 4=Agree, 5=Strongly Agree 
As per Table 4 above on religious symbols, the statement contained in CB1 titled 'my employer respects my freedom of dressing according to my religious beliefs' got the highest mean value (4.0922) while statement in CB2 titled 'my employer give freedom to me to display religious decorations in the workplace' has the lowest mean value (3.5823). This means although they are satisfied about freedom of dressing as per religious belief, they show neutral or divided opinion on displaying religious decorations. As a whole, the workers somewhat agreed that they have freedom regarding religious symbols at their workplaces.

Table 5: Recruitment, Promotion, and Training

\begin{tabular}{|c|c|c|c|}
\hline No. & Item & Mean & $\begin{array}{l}\text { Standard } \\
\text { deviation }\end{array}$ \\
\hline $\mathrm{CC} 1$ & $\begin{array}{l}\text { My employer applying laws that provide equal } \\
\text { employment and promotion opportunity for all } \\
\text { employees regardless of their race, skin colour, religion, } \\
\text { gender, etc. }\end{array}$ & 3.8801 & .96788 \\
\hline $\mathrm{CC} 2$ & $\begin{array}{l}\text { My employer does not discriminate on grounds of } \\
\text { religion in terms of recruitment and work conditions. }\end{array}$ & 3.8603 & .96727 \\
\hline $\mathrm{CC} 3$ & $\begin{array}{l}\text { My employer only employs staff with their favourable } \\
\text { religions. }\end{array}$ & 2.4348 & 1.26997 \\
\hline $\mathrm{CC} 4$ & My employer organises talks on religious tolerance. & 3.1199 & 1.11128 \\
\hline $\mathrm{CC5}$ & $\begin{array}{l}\text { My employer allows staffs to conduct activities and } \\
\text { training on religious belief and practices. }\end{array}$ & 3.3426 & 1.10703 \\
\hline
\end{tabular}

Note: Scale 1=Strong Disagree, 2=Disagree, 3=Neutral, 4=Agree, 5=Strongly Agree

In terms of recruitment, promotion and training, the respondents get divided and show neutral opinion in almost all the statements in Table 5. Among the statements, CC1 titled 'my employer applies laws that provide equal employment and promotion opportunity for all employees regardless of their race, skin colour, religion, gender, etc.' got the highest mean value of 3.8801, whereas, statement CC3 titled 'my employer only employs staff with their favourable religions' got the lowest mean value of 2.435. As none of the statements achieved scale of agree or strongly agree, it is observed that the workers neither deny nor fully agree on religious freedom in case of recruitment, promotion and training. However, the shared that their employers did not practiced discrimination for the employment purposes. 
Table 6: Religious Observants

\begin{tabular}{|c|c|c|c|}
\hline No. & Item & Mean & $\begin{array}{l}\text { Standard } \\
\text { deviation }\end{array}$ \\
\hline CD1 & $\begin{array}{l}\text { I was given a time off to perform my daily prayer or other } \\
\text { religious observance. }\end{array}$ & 4.3017 & .84864 \\
\hline CD2 & $\begin{array}{l}\text { My employer accommodates my requests to be excused } \\
\text { from performing particular duties that seems to be } \\
\text { contradicted with my religious norms. }\end{array}$ & 4.0993 & .93183 \\
\hline CD3 & $\begin{array}{l}\text { My employer gives support to any religious celebrations } \\
\text { of important events. }\end{array}$ & 4.0725 & .84483 \\
\hline CD4 & I was granted to apply leave for my religious festivals. & 4.0922 & .87440 \\
\hline CD5 & $\begin{array}{l}\text { I was allowed to promote and debate my religious } \\
\text { doctrine among colleagues at the workplace. }\end{array}$ & 3.4638 & 1.07794 \\
\hline
\end{tabular}

Note: Scale 1=Strong Disagree, 2=Disagree, 3=Neutral, 4=Agree, 5=Strongly Agree

Table 6 shows that in case of religious observance, most of the items were reported to have agreement from the respondents especially with regards to statement 'I was given a time off to perform my daily prayer or other religious observance' with the highest mean value of 4.302. This indicates that most of the workers agreed that they were given time to perform prayers or other observance. On the other hand, statement in CD5 titled 'I was allowed to promote and debate my religious doctrine among colleagues at the workplace' has the lowest mean value of 3.464. This indicates that they neither agree nor disagree on this statement. However, the overall result shows that most of the workers were satisfied with the freedom they got from their employers to perform religious observance.

Table 7: Religious Facilities

\begin{tabular}{|l|l|l|l|}
\hline No. & Item & Mean & $\begin{array}{l}\text { Standard } \\
\text { deviation }\end{array}$ \\
\hline CE1 & $\begin{array}{l}\text { Space for prayer and meditation is provided at my } \\
\text { workplace. }\end{array}$ & 4.227 & .93550 \\
\hline CE2 & $\begin{array}{l}\text { I am satisfied with the facilities provided at my } \\
\text { workplace to perform daily prayer or other religious } \\
\text { observance. }\end{array}$ & 4.1989 & .91813 \\
\hline CE3 & $\begin{array}{l}\text { When workplace events are held, my employer are aware } \\
\text { of food restrictions and offer meal that can } \\
\text { accommodate all employees' beliefs. }\end{array}$ & $\mathbf{4 . 2 6 7 8}$ & .87318 \\
\hline CE4 & $\begin{array}{l}\text { I am aware the staff is allowed to contribute anything on } \\
\text { the cultures, religions and ethic celebrations in the } \\
\text { company's social media facility. }\end{array}$ & $\mathbf{3 . 9 3 0 6}$ & .91188 \\
\hline CE5 & $\begin{array}{l}\text { My employer provides special leaves facilities for me to } \\
\text { perform religious obligations (umrah, hajj, vanares, etc). }\end{array}$ & 4.1889 & .95052 \\
\hline
\end{tabular}

Note: Scale 1=Strong Disagree, 2=Disagree, 3=Neutral, 4=Agree, 5=Strongly Agree 


\section{1 | International Journal of Scientific and Management Research 4(5) 80-96}

In terms of religious facilities provided by the employer, almost all the workers give positive responses in all the statements in Table 7. Out of the five statements, CE3 titled 'When workplace events are held, my employer are aware of food restrictions and offers meal that can accommodate all employees' beliefs' has the highest mean value (4.268) while statement CE4 titled 'I am aware the staff is allowed to contribute anything on the cultures, religions and ethic celebrations in the company's social media facility' has the lowest mean value (3.931). Hence, the workers are satisfied with the religious facilities provided by their employer.

\section{Exploratory Factor Analysis for Religious Diversity Practices}

In order to estimate the data normally distributed, Skewness \& Kurtosis standard error analysis is done and the value should be less than 2 (Skewness Std. error $<1.96$ ) and Kurtosis standard error $<1.96$ ). According to the analysis, all the items did not exceed 2 for both skewness and kurtosis standard error. Therefore, the data were normally distributed. Further than that, based on sampling adequacy test (KMO and Bartlett's Test), the values represent that the sampling of this research is adequate for further analysis which is 0.922 (significant at 0.000 ).

\section{Table 8: Sampling adequacy test}

\section{KMO and Bartlett's Test}

\begin{tabular}{|c|c|c|}
\hline \multicolumn{2}{|c|}{ Kaiser-Meyer-Olkin Measure of Sampling Adequacy. } & .922 \\
\hline & Approx. Chi-Square & 14717.041 \\
\hline \multirow[t]{2}{*}{ Bartlett's Test of Sphericity } & $d f$ & 820 \\
\hline & Sig. & .000 \\
\hline
\end{tabular}

Factor analysis is then conducted to confirm all measurement items used to measure each of the religious diversity practices in Malaysia which are company policy, religious symbols, recruitment, promotion, and training, religious observants, and facilities. Results of factor analysis is presented in Table 9 and 10 below. 


\section{2 | International Journal of Scientific and Management Research 4(5) 80-96}

Table 9: Total Variance explained

\begin{tabular}{|c|c|c|c|c|c|c|c|c|c|}
\hline \multicolumn{10}{|c|}{ Total Variance Explained } \\
\hline \multirow[b]{2}{*}{ Component } & \multicolumn{3}{|c|}{ Initial Eigenvalues } & \multicolumn{3}{|c|}{$\begin{array}{|llll|}\text { Extraction Sums of Squared } \\
\text { Loadings }\end{array}$} & \multicolumn{3}{|c|}{\begin{tabular}{|llll} 
Rotation & Sums & of & Squared \\
Loadings & & & \\
\end{tabular}} \\
\hline & Total & $\begin{array}{l}\% \text { of } \\
\text { Variance }\end{array}$ & $\begin{array}{l}\text { Cumulative } \\
\%\end{array}$ & Total & \begin{tabular}{|l|}
$\%$ of \\
Variance
\end{tabular} & $\begin{array}{l}\text { Cumulative } \\
\%\end{array}$ & Total & $\begin{array}{l}\% \text { of } \\
\text { Variance }\end{array}$ & $\begin{array}{l}\text { Cumulative } \\
\%\end{array}$ \\
\hline 1 & 12.066 & 43.093 & 43.093 & 12.066 & 43.093 & 43.093 & 5.770 & 20.607 & 20.607 \\
\hline 2 & 2.755 & 9.840 & 52.933 & 2.755 & 9.840 & 52.933 & 5.664 & 20.230 & 40.837 \\
\hline 3 & 2.050 & 7.323 & 60.256 & 2.050 & 7.323 & 60.256 & 3.325 & 11.876 & 52.713 \\
\hline 4 & 1.512 & 5.401 & 65.658 & 1.512 & 5.401 & 65.658 & 2.759 & 9.853 & 62.566 \\
\hline 5 & 1.179 & 4.212 & 69.870 & 1.179 & 4.212 & 69.870 & 1.588 & 5.673 & 68.239 \\
\hline 6 & 1.077 & 3.847 & 73.717 & 1.077 & 3.847 & 73.717 & 1.534 & 5.477 & 73.717 \\
\hline 7 & .881 & 3.145 & 76.862 & & & & & & \\
\hline 8 & .791 & 2.826 & 79.688 & & & & & & \\
\hline 9 & .715 & 2.554 & 82.243 & & & & & & \\
\hline 10 & .639 & 2.281 & 84.524 & & & & & & \\
\hline 11 & .560 & 2.001 & 86.525 & & & & & & \\
\hline 12 & .524 & 1.871 & 88.395 & & & & & & \\
\hline 13 & .474 & 1.694 & 90.089 & & & & & & \\
\hline 14 & .432 & 1.541 & 91.631 & & & & & & \\
\hline 15 & .383 & 1.367 & 92.998 & & & & & & \\
\hline 16 & .331 & 1.183 & 94.181 & & & & & & \\
\hline \begin{tabular}{|l}
17 \\
\end{tabular} & .301 & 1.075 & 95.256 & & & & & & \\
\hline 18 & .212 & .757 & 96.012 & & & & & & \\
\hline 19 & .197 & .703 & 96.715 & & & & & & \\
\hline 20 & .175 & .624 & 97.339 & & & & & & \\
\hline 21 & .158 & .564 & 97.903 & & & & & & \\
\hline 22 & .136 & .487 & 98.390 & & & & & & \\
\hline 23 & .114 & .407 & 98.797 & & & & & & \\
\hline 24 & .106 & \begin{tabular}{|l|}
.377 \\
\end{tabular} & 99.174 & & & & & & \\
\hline 25 & .083 & .295 & \begin{tabular}{|l|}
99.469 \\
\end{tabular} & & & & & & \\
\hline 26 & .067 & .238 & 99.707 & & & & & & \\
\hline 27 & .045 & .159 & 99.866 & & & & & & \\
\hline 28 & .037 & .134 & \begin{tabular}{|l|}
100.000 \\
\end{tabular} & & & & & & \\
\hline
\end{tabular}


Table 10: Communalities

\begin{tabular}{|c|c|c|}
\hline & Initial & Extraction \\
\hline CA1 & 1.000 & .663 \\
\hline CA2 & 1.000 & .604 \\
\hline CA3 & 1.000 & .654 \\
\hline CA4 & 1.000 & .565 \\
\hline CA5 & 1.000 & .621 \\
\hline CB1 & 1.000 & .560 \\
\hline CB2 & 1.000 & .676 \\
\hline CB3 & 1.000 & .701 \\
\hline CB4 & 1.000 & .572 \\
\hline CB5 & 1.000 & .731 \\
\hline CB6 & 1.000 & .713 \\
\hline $\mathrm{CC} 1$ & 1.000 & .784 \\
\hline $\mathrm{CC} 2$ & 1.000 & .781 \\
\hline CC4 & 1.000 & .747 \\
\hline CC5 & 1.000 & .720 \\
\hline CD1 & 1.000 & .654 \\
\hline CD2 & 1.000 & .582 \\
\hline CD3 & 1.000 & .617 \\
\hline CD4 & 1.000 & .545 \\
\hline CE1 & 1.000 & .689 \\
\hline CE2 & 1.000 & .492 \\
\hline CE3 & 1.000 & .583 \\
\hline CE5 & 1.000 & .617 \\
\hline CE4 & 1.000 & .547 \\
\hline
\end{tabular}

Based on the results of EFA in Table 9, there are six factors with eigenvalues more than 1 which represents $73.71 \%$ of total variance explained. Its means, from total of 28 measurements items, it seems to measure six underlying factors for diversity religious practices as measured in this study which are company policy, dress code, religious symbols or artifacts, recruitment/ promotion/training, religious observances, and facilities. Further than this, results of communalities indicate that all items have high communalities where the value of $r$ square are more than 0.5. It thus signifies the measurement items used in this study is strong enough to observe the religious diversity among public and private employees in Malaysia.

\section{Findings and Conclusion}

The current study attempts to reveal the extent of religious diversity practices at Malaysian public and private sector workplaces from the workers' point of view. After detailed analysis of the data from the respondents of all states of Malaysia, it is found that public and private sector workers in Malaysia enjoy freedom of religion in their workplaces irrespective of their religious belief. In this case, it is certain that religious tolerance is highly considered in Malaysian workforce environment. Hoffman (2020) have illustrated that the major influence of religious tolerance are religious behaviour and practices. Even though there are diversity of religion practices in Malaysia, the 


\section{4 | International Journal of Scientific and Management Research 4(5) 80-96}

findings suggest that there were no issue for both public and private sectors to allow their employees to practice their religion (positive religious tolerance). This basically contradict with the results of Hoofman (2020) study on the Arab country where the author found that religious practices or attendance have reduced tolerance attitude among the Arab people as frequent attendance for communal worship have increased distinct from members of other groups or religions.

In almost all workplaces there are written policies and practices to deal with religious freedom and the employees are aware about these rules. Moreover, in most workplaces the employer offer guidelines in relation to religious tolerance and give the right to manifest workers' religion. In most cases, company policies do not allow to hire people from certain religious background only (Table 3). The employers also recognize the workers' freedom of dressing according to their religious belief and in limited cases allow the workers to display religious artifacts though most of the workers opined that they are free to wear any religious symbol at workplace. It is also found that the employers usually do not impose restrictions in wearing certain religious dress such as headscarves or turbans. The workers are also free to use religious words and discuss religious matters with the colleagues (Table 4). In case of recruitment, promotion and training the employers usually apply equal opportunity principle though in some cases they employ staff from their favourable religion. In some workplaces the employer organizes talks on religious tolerance and allow staff to conduct training on religious belief and practices (Table 5). Almost all the employers allow their workers to perform their religious chores, even give them time off or leave for religious events or festivals. (Table 6). In most of the workplaces, there are space for prayers and meditation and the workers seem satisfied with such facilities. The employers respect the religious belief of workers in case of food supplies too. Special leaves are also allowed to workers to perform certain religious obligations, such as umrah, hajj, vanares etc. (Table 7).

In conclusion, it can be said that religious freedom is practiced in most of the public and private sector workplaces in Malaysia. Malaysia has achieved this tremendous quality of religious diversity practices from it decades old multicultural and multireligious society. However, absolute religious freedom may also be a boomerang for the organization and may involve the workers from diverse religious background in conflict, and thus resulting adverse effect for the organization. Hence, religious diversity would lead to many advantages to the organization which including innovation where they work together regardless their background and create the atmosphere that can accommodate all idea (Hicks, 2002). It is also proven by previous researchers that when employees feel comfortable to practice their religious at work and feeling welcome to share their religious identity it may reduce burnout, increase job satisfaction, and commitment (Gelb \& Longacre, 2012). Religious diversity should be handled rather than wished away by barring the whole topic from discussion. As this research is conducted from the workers' perspective, there is always scope of further research on the same matter from the employers' point of view. 
This work was supported by the Fundamental Research Grant Scheme (FRGS) from the Malaysian Ministry of Higher Education [grant numbers FRGS19-0490657/FRGS/1/2018/SS03/UIAM/01/3]

Data availability statement (DAS) - Data collected in this research (via survey) is remain anonymous with the researchers, it will be forwarded to the journal committee upon request.

\section{References}

1) Abdul Rahman, Nur Farhana \& Mohd Khambali@Hambali, Khadijah (2013). Religious Tolerance in Malaysia: Problems and Challenges, International Journal of Islamic Thought (IJIT), Vol. 3, pp. 81-91

2) Abubakar, Ibrahim (2013). The religious Tolerance in Malaysia: An Exposition, Advances in Natural and Applied Sciences, 7(1), pp. 90-97

3) Department of Statistics Malaysia, Population Distribution and Basic Demographic Characteristic Report 2010. Accessed on 10 March 2021.

4) European Network against Racism, "Managing Religious Diversity in the Workplace: A Good Practice Guide," (European Network against Racism, Dec 2015).

5) Hicks, D. (2002). Spiritual and religious diversity in the workplace: Implications for leadership. The Leadership Quarterly, 13(4), 379-396.

6) Hoffman, M (2020). Religion and Tolerance of Minority Sects in the Arab World, Journal of Conflict Resolution, 64 (2-3), pp. 432-458

7) International Commission of Jurists (2019). Challenges to Freedom of Religion or Belief in Malaysia, A Briefing Paper, pp. 3-4

8) Lucy Vickers (2015). Religion and the Workplace, the Equal Rights Review, Volume-14, pp. 106-118. Available at $<$ https://www.equalrightstrust.org/ertdocumentbank/Vickers.pdf $>$ Accessed 10 October 2020.

9) Messarra, Leila Canaan (2014). Religious Diversity at Work: The Perceptual Effects of Religious Discrimination on Employee Engagement and Commitment, Contemporary Management Research, 10 (1), pp. 59-80

10) Mitroff, I. and Denton, E. (1999). A Spiritual Audit of Corporate America: A HardLook at Spirituality, Religion, and Values in the Workplace. San Francisco: Jossey-Bass; Cavanagh, G. (1999). Spirituality for managers: context and critique. Journal of Organizational Change Management, 12(3), 186-199.

11) Mohd Arip Kasmo, Abur Hamdi Usman, Mohamad Taha, Ahmad Rafizi Salleh \& Jamsari Alias (2015). Religious Tolerance in Malaysia: A Comparative Study between the Different Religious Groups, Review of European Studies; 7 (3), pp. 184-191

12) Nur Amali Aminnuddin (2020). Ethnic differences and predictors of racial and religious discriminations among Malaysian Malays and Chinese, Cogent Psychology, 7:1, DOI: $10.1080 / 23311908.2020 .1766737$ 
96 | International Journal of Scientific and Management Research 4(5) 80-96

13) Oliveira, Arnaldo (2004). The place of spirituality in organizational theory. Electronic Journal of Business Ethics and Organization Studies (EJBO), 9(2), 17-22XX;

14) Opportunities and challenges, Business Horizon, 55, 509-518

15) The Federal Constitution of Malaysia, Article 11(1)

16) The Federal Constitution of Malaysia, Article 11(5)

17) The Federal Constitution of Malaysia, Article 3(1)

18) The Federal Constitution of Malaysia, Article 8(2)

19) Vimala Kadiresan and Najwa Khalid Javed (2015) Discrimination in Employment and Task Delegation at Workplace in the Malaysian Context, International Journal of Academic Research in Business and Social Sciences, 5 (6), pp. 37

20) Abdullah, Muhammad Ridhuan Tony Lim., Al-Amin, M Nuri., Yusoff, Atifah., Baharuddin, Azizan., Abdul Khir, Faizal., Talib, Ahmad Tarmizi. (2016). Socio-Religious Harmony Index Instrument Indicators for Malaysia, Jurnal al-Tamaddun, 11(2), 29-44

\section{Works Cited}

Marhanum Che Mohd Salleh, Nik Ahmad Kamal Nik Mahmod, Azmi Bin Harun, Azizah Mohd, Noor Azlan B. Mohd Noor, \& Rahmawati Binti Mohd Yusoff. (n.d.). An Empirical Investigation on Religious Diversity Practices at Malaysian Private and Public Sectors. International Journal of Scientific and Management Research, 04(05), 80-96. doi:http://doi.org/10.37502/IJSMR.2021.4504 